\title{
Improvement in Sleep Duration was Associated with Higher Cognitive Function among Middle-Aged and Elderly Chinese Participants
}

\section{Jianian Hua ${ }^{12}$, Hongpeng Sun ${ }^{3, *}$ and Yueping She $e^{4, * *}$}

${ }^{1}$ Department of Neurology, The First Affiliated Hospital of Soochow University, Suzhou, Jiangsu, China, 899 Pinghai Road, Suzhou, 215000, PR China.

${ }^{2}$ Medical College of Soochow University, Suzhou 215123, PR China.

${ }^{3}$ Department of Child Health, School of Public Heath, Medical College of Soochow University, 199 Renai Road, Suzhou, 215123, PR China.

${ }^{4}$ Department of Epidemiology and Biostatistics, School of Public Heath, Medical College of Soochow University, 199 Renai Road, Suzhou, 215123, PR China.

\section{* Correspondence:}

Hongpeng Sun

hpsun@suda.edu.cn; Tel.: +86 51265880076 (H.S.).

\section{**Correspondence:}

Yueping Shen

shenyueping@suda.edu.cn; Tel.: +86 51265883323 (Y.S.). 
medRxiv preprint doi: https://doi.org/10.1101/2020.04.09.20060277; this version posted April 14, 2020. The copyright holder for this preprint (which was not certified by peer review) is the author/funder, who has granted medRxiv a license to display the preprint in perpetuity.

All rights reserved. No reuse allowed without permission.

\section{Abstract}

Study objectives: Rodent studies suggested that improvement in sleep duration might correlate with better cognitive function. We aimed to examine the associations between changes in sleep duration and cognitive function.

Methods: 10325 individuals from the China Health and Retirement Longitudinal Study (CHARLS) were included. Self-reported nocturnal sleep duration and cognitive function were assessed in CHARLS 2011, 2013 and 2015 (Wave 1, Wave 2, Wave3). Cognitive function was assessed by a global cognition score, which included three domains: episodic memory, figure drawing and Telephone Interview of Cognitive Status (TICS). Generalized additive models (GAM) and Generalized estimation equations (GEE) were used to examine the associations between baseline sleep duration and longitudinal cognitive function. We used generalized linear models (GLM) to study the associations between changes in sleep duration and cognitive function in Wave 3.

Results: After adjusting for potential confounders, change from short sleep duration (SSD) to moderate sleep duration (MSD) was associated with better global cognition scores $(\beta=0.54, \mathrm{P}<0.01)$. Change from SSD to long sleep duration $(\mathrm{LSD})(\beta=-0.94, \mathrm{P}<0.001)$ or change from LSD to SSD $(\beta=-1.38, \mathrm{P}$ $<0.01)$ was associated with lower global cognition. For individuals with $\mathrm{MSD}, \geq 2 \mathrm{~h}$ increase $(\beta=-0.89$, $\mathrm{P}<0.001)$ or decrease $(\beta=-0.70, \mathrm{P}<0.001)$ in sleep duration was associated with lower global cognition. Conclusions: For short sleepers, improvement in sleep duration correlated with better cognition. For long sleepers, there was no need to reduce sleep duration. Excessive changes or deviation from the moderate duration was associated with lower cognition.

Keywords: change in sleep duration, cognitive function, prospective study, aging, Chinese population 
medRxiv preprint doi: https://doi.org/10.1101/2020.04.09.20060277; this version posted April 14, 2020. The copyright holder for this preprint (which was not certified by peer review) is the author/funder, who has granted medRxiv a license to display the preprint in perpetuity.

All rights reserved. No reuse allowed without permission.

Abbreviations: SSD: short sleep duration; MSD: moderate sleep duration; LSD: long sleep duration.

\section{Introduction}

The World Health Organization estimated that about 40 million people were living with dementia in 2015, and the number would increase 10 million per year ${ }^{1}$. Cognitive function test is a key way to detect dementia. Since dementia causes irreversible effect on life quality and strain on global health, it is imperative to find modifiable risk factors for lower cognitive function so that we can prevent or postpone dementia.

Considerable studies have found associations between sleep and cognitive function ${ }^{2}$. A recent metaanalysis revealed an inverted-U shaped association between sleep duration and risk of Alzheimer's disease $^{3}$. In the result, compared with people with moderate sleep duration, both people with short sleep duration and long sleep duration had higher risk.

Experimental studies have showed associations between sleep, circadian rhythm, and neurodegenerative diseases, especially for Alzheimer's disease ${ }^{4,5}$. Under the guidance of this association, researchers pointed out that improvement in sleep duration might be a therapeutic target in dementia treatment or prevention ${ }^{5-7}$. Few studies have examined the effect of change in sleep duration on cognition. Limited by sample sizes or methodology, all their conclusions were that increased or decreased sleep duration was associated with lower cognitive function or higher risk of dementia $^{8-10}$. To data, no epidemiology or clinical study proved that improvement in sleep duration correlated with better cognitive function. Moreover, the association between changes in sleep duration and cognition have yet to be examined among middle-aged Chinese.

Considering the "inverted-U shaped association" mentioned above, we hypothesized that a change towards the optimal sleep duration was associated with better cognitive function while deviation from the optimal was linked to lower cognitive function. Here, a large-scale population-based prospective study, the China Health and Retirement Longitudinal Study (CHARLS), would enable us to verify our 
medRxiv preprint doi: https://doi.org/10.1101/2020.04.09.20060277; this version posted April 14, 2020. The copyright holder for this preprint (which was not certified by peer review) is the author/funder, who has granted medRxiv a license to display the preprint in perpetuity.

All rights reserved. No reuse allowed without permission.

hypothesis. The aim of our study was to: (1) re-examine the inverted-U shaped association between sleep duration and cognitive function among Chinese participants; (2) investigate the longitudinal association between baseline sleep duration and cognitive function over a period of time; (3) study the association between change in sleep duration and cognitive function.

\section{Methods}

\subsection{Study Sample}

Participants included in our study were from the China Health and Retirement Longitudinal Study (CHARLS), which was a prospective survey designed to provide scientific research related to the aged in China. The participants were non-institutionalized, aged 45 years and older and from 28 provinces in China. Baseline survey were conducted on 17708 participants between 2011 and 2012. The survey was conducted and followed up every two years ${ }^{11}$.

In the CHARLS, a total number of 15700 participants had data on sleep duration and cognitive tests in 2011 (Wave 1). 104 individuals under 45 years old till 2015 were excluded. 380 individuals with a history of brain damage or mental retardation were excluded. Among the rest 15216 participants, 12807 (84.2\%) of them were followed up and had complete data on sleep duration and cognitive tests in 2013 (Wave 2). 10325 (80.6\%) participants were followed up and had relative data in 2015 (Wave 3). The selection diagram and criteria for exclusion are provided in Figure 1.

\subsection{Assessment of cognitive function}

The cognitive dimensions of memory, visuospatial abilities, orientation, attention and calculation were assessed, through three tests: episodic memory, figure drawing, and Telephone Interview of Cognitive Status (TICS). Serving as the primary outcome, the global cognition score was the sum of the three test scores. The global cognition score could range from 0 to 21 .

In the episodic memory test, the individuals were asked to recall the words immediately (immediate recall) and 5 minutes later (delayed recall) after interviewers read 10 Chinese nouns to them. The 
medRxiv preprint doi: https://doi.org/10.1101/2020.04.09.20060277; this version posted April 14, 2020. The copyright holder for this preprint

episodic memory score was the average score of the immediate recall and delayed recall tests and could range from 0 to $10^{12}$. This test assessed individuals' memory.

In the figure-drawing test, the individuals were shown a picture and asked to redraw it. Those who succeeded in drawing got a score of 1 . If failed, they got a score of 0 . This test examined visuospatial abilities.

The TICS test was based on selected questions from the TICS battery, a well-established measure of one's ability related to orientation, attention and calculation. In this test, the participants were asked to repeatedly subtract 7 from 100 and to identify the date, season, and day of the week. The TICS scores could range from 0 to $10^{13}$.

\subsection{Assessment of sleep duration}

Nocturnal sleep duration was obtained by the following questions, "During the past month, how many hours of actual sleep did you get at night (average hours for one night)"? The data was accurate to 0.5

h.

\subsection{Potential Confounders}

The potential confounders included age, gender, education, marital status, residential area, cigarette smoking, alcohol drinking, depression, instrumental activities of daily living (IADLs), use of tranquilizers, and comorbidities.

596 participants in our study missed data on body mass index (BMI). To maximize our sample size, we did not take BMI into account ${ }^{14}$. IADLs could range from 0 to 5 and reflect functional status ${ }^{15}$. Depression was classified as "yes" and "no", using the 10-item Center for Epidemiologic Studies Short Depression Scale (CES-D-10). This score can range from 0 to 30, and the cut-off point for depression was $12^{16}$. The comorbidities included hypertension, dyslipidaemia, history of stroke, history of heart diseases $^{17}$.

\subsection{Statistical Analysis}


medRxiv preprint doi: https://doi.org/10.1101/2020.04.09.20060277; this version posted April 14, 2020. The copyright holder for this preprint (which was not certified by peer review) is the author/funder, who has granted medRxiv a license to display the preprint in perpetuity.

All rights reserved. No reuse allowed without permission.

Demographic characteristics were shown as the mean \pm SD (standard deviation) or frequency (percentage). Associations between participants' characteristics and baseline sleep duration were examined using ANOVA or the Pearson Chi-square test (Table 1).

We used generalized additive models (GAM) to examine the inverted-U shaped association between baseline sleep duration and cognitive function in Wave 1 (Figure 2) and Wave 3 (Figure 3). GAM is "an extension of the generalized linear model which allows the evaluation for the curvilinear relationship of the outcome and the predictors". The effective degree of freedom (EDF) output by GAM reflects the degree of curvature. An EDF $=1$ means linear relation, while an EDF $>1$ means more complex relations. Individuals whose sleep duration was out of mean $\pm 2 \mathrm{SD}$ were deleted temporarily ${ }^{18}$. Model 0 used global cognition score as a continuous response and a smoothing spline function of sleep duration as a univariable predictor. In model 1, the predicted variables were age, gender and smooth(sleep duration). The predicted smooth functions along with the 95\% confidence intervals were plotted ${ }^{19}$.

We categorized sleep duration into three patterns: short sleep duration (SSD), <6 h; moderate sleep duration (MSD), 6-8h; long sleep duration (LSD), >8h. All previous literature chose $6 \mathrm{~h}$ as the lower cut-off point. For the mean sleep duration of our participants was $6.4 \mathrm{~h}$ and our participants' optimal sleep duration for global cognition was about $7 \mathrm{~h}$, we chose $8 \mathrm{~h}$ as the upper cut-off point.

Generalized estimation equations (GEE) were used to extend the GAM for further analysis of the longitudinal association between baseline sleep duration and cognitive function over a period of 4 years. GEE accounted for between-participant variation and within-participant correlation of repeated outcomes. Time was defined as a continuous variable, measured as years from baseline. In model 1 and model 2, we calculated the estimates of sleep duration (Table 2), to examine the association between baseline sleep duration and cognition. In model 3, we calculated the estimates of interaction of time and sleep duration, to study the rate of cognitive decline $\mathrm{e}^{20,21}$. 
medRxiv preprint doi: https://doi.org/10.1101/2020.04.09.20060277; this version posted April 14, 2020. The copyright holder for this preprint (which was not certified by peer review) is the author/funder, who has granted medRxiv a license to display the preprint in perpetuity.

All rights reserved. No reuse allowed without permission.

To analyse associations between change in sleep duration and cognition, we used generalized linear models (GLM), after adjustment for potential confounders.

As discussed above, the global cognition score was the primary outcome. Associations with the three cognition tests included in the global cognition score were examined in complementary analyses and shown in supplementary material. GAM was carried out using R-3.4.3. Other statistical analyses were performed by SAS version 9.4 (SAS Institute Inc., Cary, North Carolina, USA).

\section{$3 \quad$ Results}

\subsection{Demographic and health characteristics of the study population in Wave 1}

In wave 1 , the mean age of all participants was $59.1 \pm 9.8$ years; $47.3 \%$ of the participants were male, $76.5 \%$ of them were from rural areas, and $88.0 \%$ of them were married. With regard to education, $73.3 \%$ of the participants attended primary school and above. The mean \pm SD nocturnal sleep duration was $6.4 \pm 1.9$ hours per night. At baseline, $62.5 \%$ of the participants were moderate sleepers $(6-8 \mathrm{~h}), 29.2 \%$ of them were short sleeps $(<6 \mathrm{~h})$, while only $8.2 \%$ of them were long sleepers $(>8 \mathrm{~h}) .0 .3 \%$ individuals used tranquilizers.

In wave 1 , the mean age of moderate sleepers was 2.9 years younger than short sleepers and 1.6 years younger than long sleepers (Table 1). Moderate sleepers were more likely to be male, live in urban areas, have better education, and get married. Moderate sleepers had a slightly higher BMI and lower number of IADLs, and they more often smoke and drunk. Long sleepers were more likely to suffer from depression. Short sleepers were more likely to have a history of hypertension, dyslipidemia, heart disease and stroke, while moderate sleepers tended to be healthier (Table 1).

Table 1. Demographic and health characteristics of the study population in Wave $1^{*}$

\begin{tabular}{lllllll}
\hline & $<6 \mathrm{~h}(\mathrm{n}=4453)$ & $6-8 \mathrm{~h}(\mathrm{n}=9508)$ & $>8 \mathrm{~h}(\mathrm{n}=1255)$ & $\begin{array}{l}\text { All } \\
(\mathrm{n}=15216)\end{array}$ & $P^{\mathrm{a}}$ & $P^{\mathrm{b}}$ \\
\hline \multicolumn{7}{l}{} \\
\hline age
\end{tabular}


medRxiv preprint doi: https://doi.org/10.1101/2020.04.09.20060277; this version posted April 14, 2020. The copyright holder for this preprint (which was not certified by peer review) is the author/funder, who has granted medRxiv a license to display the preprint in perpetuity.

All rights reserved. No reuse allowed without permission.

\begin{tabular}{lllllll} 
Number of IADLs & $0.3(0.9)$ & $0.2(0.6)$ & $0.3(0.9)$ & $0.2(0.7)$ & $<0.001$ & $<0.001$ \\
\hline & Categorical Variables, $\mathrm{n}(\%)$ & & & & \\
\hline Males & $1889(42.4)$ & $4711(49.6)$ & $587(46.9)$ & $7187(47.3)$ & $<0.001$ & 0.073 \\
Education & & & & $<0.001$ & $<0.001$ \\
Illiterate & $1492(33.5)$ & $2153(26.7)$ & $415(33.1)$ & $4060(26.7)$ & \\
Primary school & $1872(42.1)$ & $3667(38.6)$ & $513(40.9)$ & $6052(39.8)$ & \\
Middle school & $732(16.5)$ & $2211(23.3)$ & $222(17.7)$ & $3165(20.8)$ & & \\
High school and above & $354(8.0)$ & $1470(15.5)$ & $105(8.4)$ & $1929(12.7)$ & & \\
Marital status & & & & & $<0.001$ & $<0.001$ \\
Married & $3742(84.0)$ & $8566(90.1)$ & $1085(86.5)$ & $13393(88.0)$ & & \\
Other status & $711(16.0)$ & $959(9.9)$ & $170(13.5)$ & $1823(12.0)$ & & \\
Residential area & & & & & $<0.001$ & $<0.001$ \\
Urban & $847(19.1)$ & $2522(26.6)$ & $205(16.4)$ & $3574(23.5)$ & & \\
Rural & $3600(81.0)$ & $6975(73.4)$ & $1047(83.6)$ & $11622(76.5)$ & & \\
Depression & $301(6.8)$ & $654(6.9)$ & $118(9.5)$ & $1073(7.1)$ & 0.795 & 0.001 \\
Use of tranquilizers & $25(0.6)$ & $20(0.2)$ & $4(0.0)$ & $49(0.3)$ & $<0.001$ & 0.444 \\
Current smoker & $1660(37.2)$ & $3799(40.0)$ & $467(37.2)$ & $5926(39.0)$ & 0.001 & 0.062 \\
Current drinker & $1040(23.4)$ & $2467(26.0)$ & $276(22.0)$ & $3783(24.9)$ & 0.003 & 0.003 \\
Hypertension & $1187(26.7)$ & $2193(22.9)$ & $329(25.5)$ & $3688(24.2)$ & $<0.001$ & 0.044 \\
Dyslipidaemia & $447(10.0)$ & $848(8.9)$ & $103(8.2)$ & $1397(9.2)$ & 0.032 & 0.411 \\
History of heart disease & $680(15.3)$ & $1041(11.1)$ & $118(9.4)$ & $1839(12.1)$ & $<0.001$ & 0.097 \\
History of stroke & $122(2.7)$ & $163(1.7)$ & $27(2.2)$ & $312(2.1)$ & $<0.001$ & 0.269 \\
\hline
\end{tabular}

${ }^{*}$ Three groups were categorized by the sleep duration in Wave 1 .

${ }^{\text {a }} P$ value for participants slept $<6 \mathrm{~h}$ in Wave 1 compared with those slept 6-8 $\mathrm{h}$.

${ }^{\mathrm{b}} P$ value for participants slept $>8 \mathrm{~h}$ in Wave 1 compared with those slept 6-8 h.

\subsection{Associations between baseline sleep duration and cognitive function}

\subsubsection{Baseline sleep duration and cognitive function in Wave 1 and Wave3}

The result of GAM for global cognition score and sleep duration indicated a non-linear fit in Wave $1(\mathrm{EDF}=7.44, P<0.001$, Figure 2$)$ and Wave $3(\mathrm{EDF}=3.71, P<0.001$, Figure 3$)$. We found an invertedU shaped cross-sectional association of sleep duration and global cognition score. The highest global cognition scores in Wave 1 and in Wave 3 were both probably observed among those sleeping 6-8 h per night in Wave 1. Remarkably, people sleeping $3 \mathrm{~h}$ or $11 \mathrm{~h}$ showed similar mean scores whichever wave.

\subsubsection{Baseline sleep duration and longitudinal cognitive function in three Waves}

Short sleepers in Wave 1 had lower global cognition scores $(\beta=-0.94, P<0.001$ for model 1 and $\beta=-$ $0.53, P<0.001$ for model 2), compared with moderate sleepers (Table 2). The specific domains were all three functions: episodic memory, figure drawing, and TICS (supplementary material). Expressed in age equivalents and compared to moderate sleep duration group, the effect of short sleep was 
medRxiv preprint doi: https://doi.org/10.1101/2020.04.09.20060277; this version posted April 14, 2020. The copyright holder for this preprint (which was not certified by peer review) is the author/funder, who has granted medRxiv a license to display the preprint in perpetuity.

All rights reserved. No reuse allowed without permission.

equivalent to being 9 (model 1) or 5 (model 2) years older for global cognition score (data not shown). Longer sleepers in Wave 1 had lower global cognition scores $(\beta=-1.05, P<0.001$ for model 1 and $\beta=-$ $0.59, P<0.001$ for model 2), compared to participants with a moderate sleep duration. The specific domains were all three tests. Expressed in age equivalents and compared to moderate sleep duration group, the effect of long sleep time was equivalent to being 11 (model 1) or 6 (model 2) years older for global cognition score.

Linear trends were also significant. For participants slept $\leq 7 \mathrm{~h}$ in Wave 1, lower sleep duration was associated with lower scores in global cognition $(\beta=0.48, P<0.001$ for model 1 and $\beta=0.28, P<0.001$ for model 2) and all three tests. For participants slept $\geq 7 \mathrm{~h}$ in Wave 1, higher sleep duration was associated with lower scores in global cognition $(\beta=-0.47, P<0.001$ for model 1 and $\beta=-0.28, P<0.001$ for model 2) and all three tests.

The sleep-duration-by-time reaction was not significant $(p>0.10$ for model 3), showing no significant association between sleep duration in Wave 1 and decline rate of global cognition score over a period of 4 years (Table 2).

Table 2. Associations between baseline sleep duration and longitudinal global cognition by generalized estimating equations (GEE)

\begin{tabular}{|c|c|c|c|}
\hline & Model $1 \beta(\mathrm{SE})$ & Model $2 \beta(\mathrm{SE})$ & Model $3 \beta(\mathrm{SE})$ \\
\hline \multicolumn{4}{|c|}{ Categorical trend } \\
\hline $\mathrm{SSD}(<6 \mathrm{~h})$ & $-0.94(0.06)^{* * *}$ & $-0.53(0.06)^{* * *}$ & \\
\hline $\operatorname{MSD}(6-8 \mathrm{~h})$ & Ref. & Ref. & \\
\hline $\operatorname{LSD}(>8 \mathrm{~h})$ & $-1.05(0.11)^{* * *}$ & $-0.59(0.09)^{* * *}$ & \\
\hline SSD*time & & & $0.02(0.02)$ \\
\hline MSD*time & & & Ref. \\
\hline LSD $*$ time & & & $-0.03(0.04)$ \\
\hline \multicolumn{4}{|c|}{ Linear trend for sleep duration $\leq 7 \mathrm{~h}$} \\
\hline Duration & $0.48(0.03)^{* * *}$ & $0.28(0.02)^{* * *}$ & \\
\hline Duration*time & & & $0.004(0.009)$ \\
\hline \multicolumn{4}{|c|}{ Linear trend for sleep duration $\geq 7 \mathrm{~h}$} \\
\hline Duration & $-0.47(0.02)^{* * *}$ & $-0.28(0.04)^{* * *}$ & \\
\hline Duration*time & & & $-0.007(0.015)$ \\
\hline
\end{tabular}

Abbreviations: SSD, short sleep duration; MSD, moderate sleep duration; LSD, long sleep duration.

${ }^{* * *} P<0.001, \beta$ : unstandardized beta coefficient, SE: standard error. 
medRxiv preprint doi: https://doi.org/10.1101/2020.04.09.20060277; this version posted April 14, 2020. The copyright holder for this preprint (which was not certified by peer review) is the author/funder, who has granted medRxiv a license to display the preprint in perpetuity.

All rights reserved. No reuse allowed without permission.

Model 1: adjusted for age and gender.

Model 2: adjusted for Model 1+ education, marital status, residential area, depression, IADLs, use of tranquilizers, smoking, drinking, hypertension, dyslipidaemia, heart disease and stroke.

Model 3: adjusted for age and gender.

\subsection{Associations between change in sleep duration and cognitive function}

\subsubsection{Participants slept 6-8 $\mathrm{h}$ in Wave 1}

In the analysis of the effect of changes in sleep duration from Wave 1 to Wave 2 (Table 3) and from Wave 1 to Wave3 (Table 4) among moderate sleepers (6-8 h) in Wave 1, we also observed an inverted U-shaped association. Changes in sleep duration that increased $(\beta=-1.30, P<0.001$ for model $1, \beta=-$ 0.83, $P<0.001$ for model 2 and $\beta=-0.63, P<0.001$ for model 3$)$ or decreased $(\beta=-0.87, P<0.001$ for model $1, \beta=-0.52, P<0.001$ for model 2 and $\beta=-0.37, P<0.001$ for model 3$) \geq 2 \mathrm{~h}$ over time were associated was lower global cognition scores than no change group (Table 3). The effect of $\geq 2 \mathrm{~h}$ change in Wave 2 was approximately equivalent to 9 years of cognitive aging in model 1, model 2, and model 3. These associations were consistent across all three cognition tests for model 1, model 2 and model 3 (supplementary material).

While analyzing the effect of change from Wave 1 to Wave 3, we found the association between changes in sleep duration and global cognition remained unchanged (Table 4). This association was across all three tests for model 1. In model 2 and model 3, figure drawing test had no significance, while episodic memory test and TICS test remained significant.

We also studied short sleepers in Wave 1, reaching a similar result that $\geq 2 \mathrm{~h}$ change in Wave 2 or Wave 3 was associated with lower global cognition scores. For long sleepers in Wave 1, the effect made no difference (data not shown).

Table 3. Associations between change in sleep duration and global cognition in Wave 2 among participants slept $6-8 \mathrm{~h}$ at baseline ${ }^{\mathrm{a}}$

Changes in sleep duration 
medRxiv preprint doi: https://doi.org/10.1101/2020.04.09.20060277; this version posted April 14, 2020. The copyright holder for this preprint (which was not certified by peer review) is the author/funder, who has granted medRxiv a license to display the preprint in perpetuity.

All rights reserved. No reuse allowed without permission.

\begin{tabular}{llllll} 
& Decreased by $\geq 2 \mathrm{~h}$ & $\begin{array}{l}\text { Decreased } \\
0.5-1.5 \mathrm{~h}\end{array}$ & by & No change & \multicolumn{2}{l}{$\begin{array}{l}\text { Increased by } 0.5- \\
1.5 \mathrm{~h}\end{array}$} & Increased by $\geq 2 \mathrm{~h}$ \\
\hline Number of subjects & 1487 & 1587 & 1690 & 1092 & 555 \\
Mean (SD) score & $7.79(3.33)$ & $8.76(3.18)$ & $8.80(3.25)$ & $8.43(3.28)$ & $7.25(3.55)$ \\
Model 1 & $-0.87(0.11)^{* * *, b}$ & $-0.03(0.11)$ & Ref. & $-0.32(0.12)^{* *}$ & $-1.30(0.16)^{* * *}$ \\
Model 2 & $-0.52(0.10)^{* * *}$ & $-0.02(0.10)$ & Ref. & $-0.14(0.11)$ & $-0.83(0.14)^{* * *}$ \\
Model3 & $-0.37(0.09)^{* * *}$ & $-0.01(0.09)$ & Ref.. & $-0.09(0.10)$ & $-0.63(0.13)^{* * *}$ \\
\hline
\end{tabular}

${ }^{a}$ Using generalized linear models (GLM).

${ }^{\mathrm{b}}$ Unstandardized beta coefficient (standard error), for all such values.

${ }^{* *} P<0.01,{ }^{* * *} P<0.001$.

Model 1: adjusted for age and gender.

Model 2: adjusted for Model 1+ education, marital status, residential area, depression, IADLs, use of tranquilizers, smoking, drinking, hypertension, dyslipidaemia, heart disease and stroke.

Model 3: adjusted for Model 2 + baseline global cognition score

Table 4. Associations between change in sleep duration and global cognition in Wave 3 among participants slept $6-8 \mathrm{~h}$ at baseline ${ }^{\mathrm{a}}$

\begin{tabular}{|c|c|c|c|c|c|}
\hline & \multicolumn{5}{|c|}{ Changes in sleep duration } \\
\hline & Decreased by $\geq 2 \mathrm{~h}$ & $\begin{array}{l}\text { Decreased } \\
0.5-1.5 \mathrm{~h}\end{array}$ & None & $\begin{array}{l}\text { Increased } \\
0.5-1.5 \mathrm{~h}\end{array}$ & Increased by $\geq 2 \mathrm{~h}$ \\
\hline Number of subjects & 1417 & 1409 & 1732 & 1138 & 794 \\
\hline Mean (SD) score & $10.06(4.25)$ & $11.39(3.91)$ & $11.51(3.92)$ & $10.07(4.10)$ & $9.57(4.31)$ \\
\hline Model 1 & $-1.17(0.14)^{* * *, b}$ & $-0.04(0.13)$ & Ref. & $-0.34(0.14)^{*}$ & $-1.56(0.17)^{* * *}$ \\
\hline Model 2 & $-0.70(0.12)^{* * *}$ & $0.02(0.12)$ & Ref. & $-0.16(0.13)$ & $-0.89(0.15)^{* * *}$ \\
\hline Model3 & $-0.43(0.11)^{* * *}$ & $0.12(0.11)$ & Ref. & $-0.09(0.11)$ & $-0.54(0.13)^{* * *}$ \\
\hline
\end{tabular}

${ }^{\mathrm{a}}$ Using generalized linear models (GLM).

${ }^{\mathrm{b}}$ Unstandardized beta coefficient (standard error), for all such values.

${ }^{*} P<0.05,{ }^{* * *} P<0.001$.

Model 1: adjusted for age and gender.

Model 2: adjusted for Model 1+ education, marital status, residential area, depression, IADLs, use of tranquilizers, smoking, drinking, hypertension, dyslipidaemia, heart disease and stroke.

Model 3: adjusted for Model 2 + baseline global cognition score

\subsubsection{Participants slept $<6 \mathrm{~h}$ in Wave 1}

The effect of sleep change on participants who slept $<6 \mathrm{~h}$ in Wave 1 was studied by sub-group analysis (Table 5). Compared to "No change" group, "Excessive" group had lower global cognition in Wave 3 ( $\beta=-1.91, P<0.001$ for model $1, \beta=-0.94, P<0.001$ for model 2 and $\beta=-0.53, P<0.05$ for model 3$)$. The specific domains included all three tests. "Benefit 1" group showed no significant difference. "Benefit 2" group had higher global cognition score $(\beta=0.55, P<0.01$ for model $1, \beta=0.54, P<0.01$ for model 2 and $\beta=0.38, P<0.05$ for model 3). The effect of "Benefit 2 " was approximately equivalent to 4-10 years aging. The specific domains were figure drawing and TICS, while episodic memory had no significance (supplementary material). 
medRxiv preprint doi: https://doi.org/10.1101/2020.04.09.20060277; this version posted April 14, 2020. The copyright holder for this preprint (which was not certified by peer review) is the author/funder, who has granted medRxiv a license to display the preprint in perpetuity.

All rights reserved. No reuse allowed without permission.

\subsubsection{Participants slept $>8 \mathrm{~h}$ in Wave 1}

The effect of sleep change on participants who slept $>8 \mathrm{~h}$ in Wave 1 was also shown in Table 5.

Compared to "No change" group, "Excessive" group had lower global cognition in Wave 3 ( $\beta=-1.38$, $P<0.01$ for model 2 and $\beta=-1.17, P<0.01$ for model 3$)$. The specific domain was episodic memory. Participants in "Benefit 1" group and "Benefit 2" group had higher global cognition scores. However, there was no significant difference after adjusted for confounders.

Table 5. Associations between change in sleep duration and global cognition in Wave 3 among participants slept $<6$ h or $>8 \mathrm{~h}$ at baseline ${ }^{\mathrm{a}}$

\begin{tabular}{|c|c|c|c|c|}
\hline & \multicolumn{2}{|c|}{ Type of change in sleep duration ${ }^{c}$} & \multirow[b]{2}{*}{ Benefit 1} & \multirow[b]{2}{*}{ Benefit 2} \\
\hline & Excessive & No change & & \\
\hline \multicolumn{5}{|l|}{ SSD $(<6 \mathrm{~h})$ in Wave 1} \\
\hline Number of subjects & 224 & 1231 & 937 & 602 \\
\hline Mean (SD) score & $7.23(4.42)$ & $9.39(4.36)$ & $9.27(4.23)$ & $10.35(4.03)$ \\
\hline Model 1 & $-1.91(0.30)^{* * *, b}$ & Ref. & $-0.31(0.18)$ & $0.55(0.20)^{* * *}$ \\
\hline Model 2 & $-0.94(0.26)^{* * *}$ & Ref. & $-0.22(0.15)$ & $0.54(0.17)^{* *}$ \\
\hline Model 3 & $-0.53(0.23)^{*}$ & Ref. & $-0.21(0.14)$ & $0.38(0.15)^{*}$ \\
\hline \multicolumn{5}{|l|}{ LSD $(>8 \mathrm{~h})$ in Wave 1} \\
\hline Number of subjects & 232 & 64 & 217 & 328 \\
\hline Mean (SD) score & $8.19(4.58)$ & $8.77(4.22)$ & $9.47(4.32)$ & $10.47(4.24)$ \\
\hline Model 1 & $-0.68(0.58)$ & Ref. & $0.22(0.54)$ & $0.80(0.54)$ \\
\hline Model 2 & $-1.38(0.52)^{* *}$ & Ref. & $-0.72(0.50)$ & $-0.34(0.52)$ \\
\hline Model 3 & $-1.17(0.45)^{* *}$ & Ref. & $-0.72(0.46)$ & $-0.43(0.46)$ \\
\hline
\end{tabular}

Abbreviations: SSD, short sleep duration; MSD, moderate sleep duration; LSD, long sleep duration.

${ }^{\mathrm{c}}$ Type of change was decided by patterns of sleep duration in Wave 2 and Wave 3

For SSD in Wave 1: Excessive, as long as one LSD in each wave; No change, remained SSD in two waves; Benefit 1, remained SSD in one wave and MSD in another; Benefit 2, MSD in two waves.

For LSD in Wave 1: Excessive, as long as one SSD in each wave; No change, remained LSD in two waves; Benefit 1, remained LSD in one wave and MSD in another; Benefit 2, MSD in two waves.

${ }^{a}$ Using generalized linear models (GLM).

${ }^{\mathrm{b}}$ Unstandardized beta coefficient (standard error), for all such values.

${ }^{*} P<0.05,{ }^{* *} P<0.01,{ }^{* * *} P<0.001$ 。

Model 1: adjusted for age and gender.

Model 2: adjusted for Model 1+ education, marital status, residential area, depression, IADLs, use of tranquilizers, smoking, drinking, hypertension, dyslipidaemia, heart disease and stroke.

Model 3: adjusted for Model 2 + baseline global cognition score

\section{$4 \quad$ Figure legends and Figures}

Figure 1. Flow chart of the sample selection and exclusion criteria. 
17708 individuals were interviewed in the first wave

(Wave 1) of CHARLS during 2011-2012

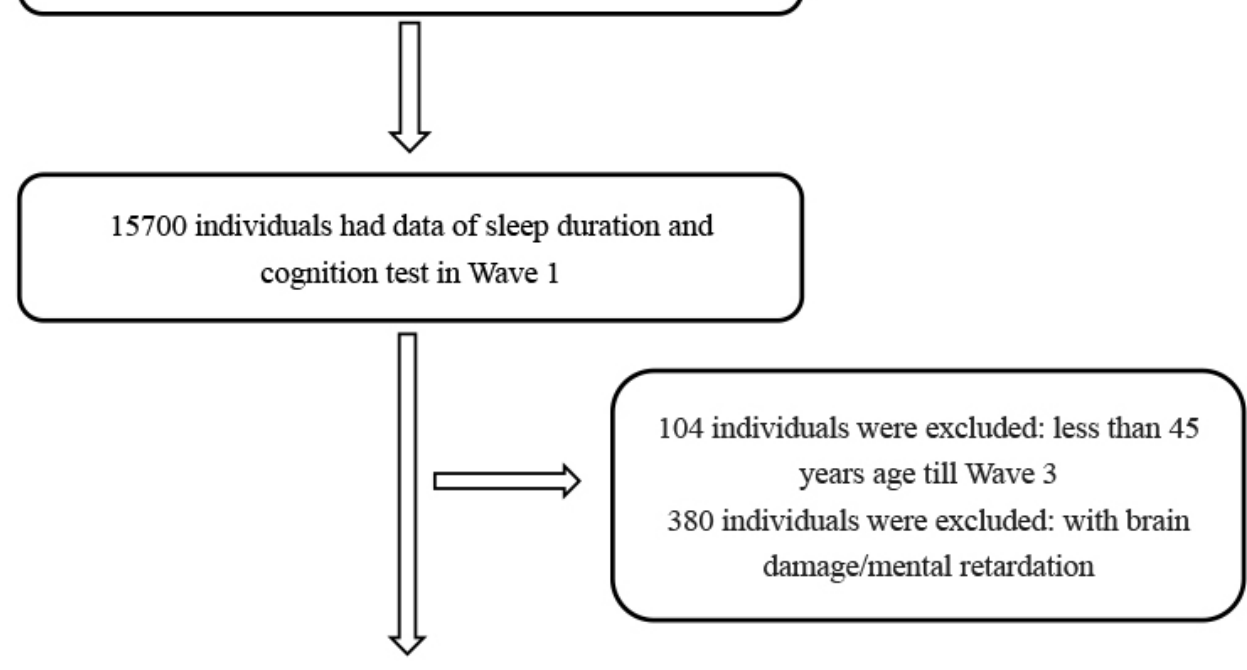

15216 individuals had data of sleep duration and cognition test in Wave 1

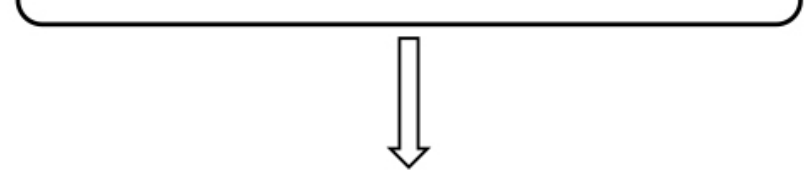

12807 individuals were followed up in Wave 2 and had data of sleep duration and cognition test in Wave 2

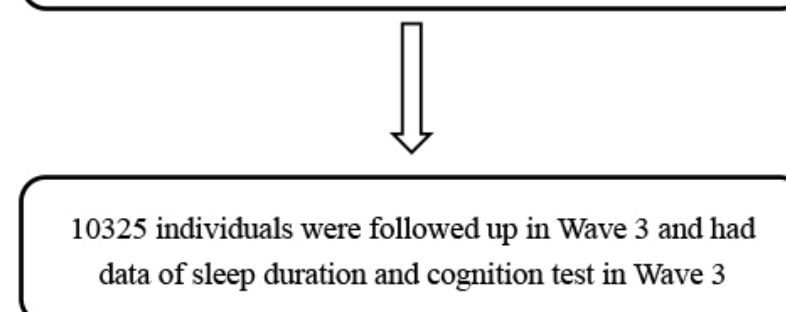

Figure 2. Plots of estimated smooth function of sleep duration in Wave 1 with $95 \%$ confidence intervals for the GAM when the response variable was global cognition in Wave 1. (A) Model 0 showed univariate smooth function of sleep duration $(\mathrm{EDF}=7.44, p<0.001)$. (B) Model 1 presented multivariable smooth function of sleep duration, adjusted for age and gender (EDF = 4,74, $p<0.001)$. 
medRxiv preprint doi: https://doi.org/10.1101/2020.04.09.20060277; this version posted April 14, 2020. The copyright holder for this preprint (which was not certified by peer review) is the author/funder, who has granted medRxiv a license to display the preprint in perpetuity.

All rights reserved. No reuse allowed without permission.

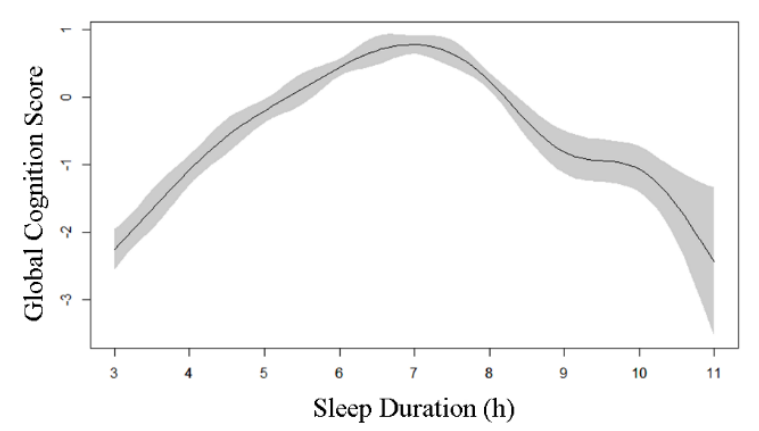

(a)

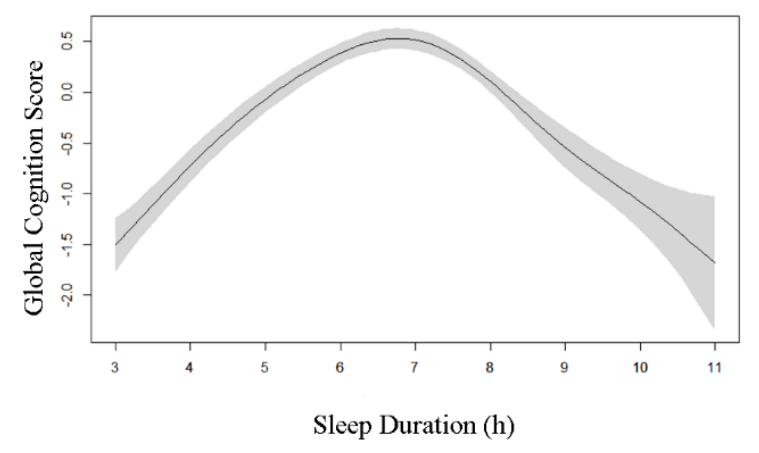

(b)

Figure 3. Plots of estimated smooth function of sleep duration in Wave 1 with $95 \%$ confidence intervals for the GAM when the response variable was global cognition in Wave 3. (A) Model 0 showed univariate smooth function of sleep duration $(\mathrm{EDF}=3.71, p<0.001)$. (B) Model 1 presented multivariable smooth function of sleep duration, adjusted for age and gender (EDF $=4.58, p<0.001)$. 


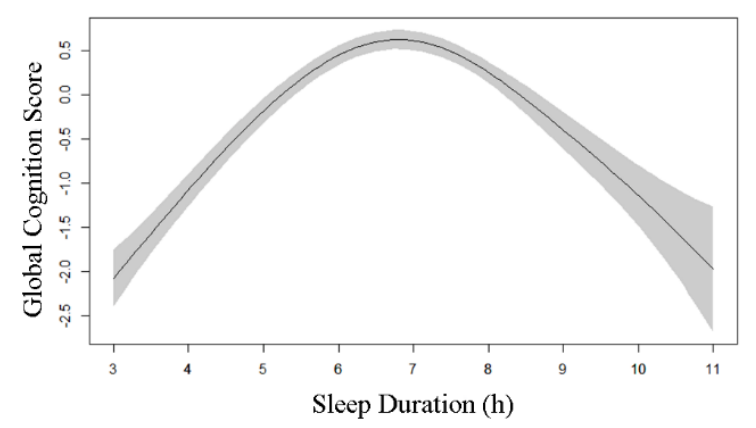

(a)

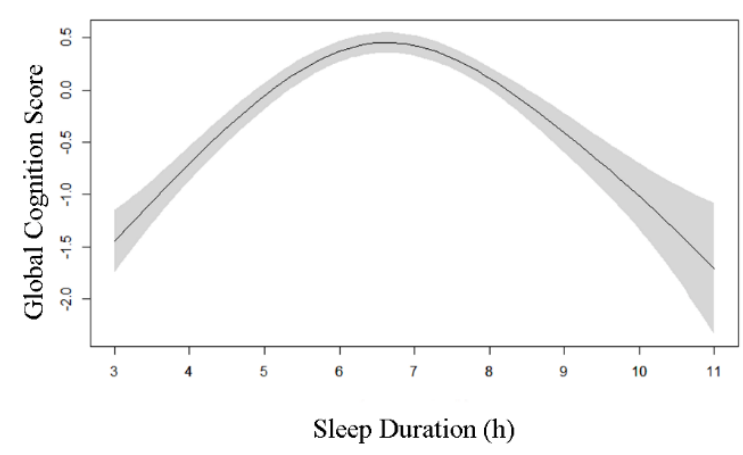

(b)

\section{Discussion}

\subsection{Synopsis of findings}

So far, this was the largest and latest study examining the longitudinal association between selfreported sleep duration and cognitive function ${ }^{3}$.Using GAM and GEE models, our study indicated an inverted-U shaped association between baseline sleep duration and global cognition over a period of 4 years, among Chinese participants. The affected domains included all tests: episodic memory, figure drawing and TICS. However, baseline sleep duration would not affect the rates of cognitive change.

For moderate sleepers, $\geq 2 \mathrm{~h}$ change in sleep duration was significantly associated with lower global cognition and all three tests. Relative to those whose sleep duration remained unchanged, a move from SSD to LSD was associated with lower global cognition, included all three tests, and a move from LSD to SSD was associated with lower episodic memory scores. For short sleepers, a consistent change to 
medRxiv preprint doi: https://doi.org/10.1101/2020.04.09.20060277; this version posted April 14, 2020. The copyright holder for this preprint (which was not certified by peer review) is the author/funder, who has granted medRxiv a license to display the preprint in perpetuity.

All rights reserved. No reuse allowed without permission.

MSD was associated with high global cognition scores, equivalent to 4-10 years of cognitive aging. The improved domains were figure drawing and TICS.

A change from LSD to MSD had no significant effect. However, only $8.2 \%$ of the participants slept LSD at baseline and $0.6 \%$ of the participants remained LSD from Wave 1 to Wave 3.

\subsection{Comparison with other studies}

The most important finding of our study was that we challenged the previous ideas that increased or decreased sleep duration would lead to lower cognition. Up to data, a total of 9 studies have examined the effect of change in sleep duration on cognitive function or risk of dementia. 5 studies linked increased sleep duration to lower cognition or higher risk of dementia ${ }^{8,10,22-24}, 1$ study linked decreased sleep duration to higher risk of $\mathrm{AD}^{25}$, and 1 study found no association ${ }^{26}$. While 2 studies reported both increase and decrease in sleep duration was associated with lower cognition ${ }^{9,27}$.

Using sub-group analysis, we discovered that a change to MSD was associated with better cognition, while a deviation from MSD or excessive change would lead to worse cognition. The following reasons could explain why conclusions of previous studies differed from ours: First, for moderate sleepers, our finding was in accordance with those studies' that a specific degree of change was harm to cognition. Second, for short sleepers, the positive effect of change to MSD was covered by the negative effect of excessive change to LSD. Third, for long sleepers, the negative effect of the $\geq 2$ hours decrease in sleep duration was caused by the change from LSD to SSD, while change from LSD to MSD was not associated with worse cognition.

Table 6 showed studies focused on change in sleep duration and used sub-group analysis. Based on the sleep duration at baseline, participants were divided into 3 groups: SSD, MSD, and LSD. The participants in the Chinese Longitudinal Healthy Longevity Survey had a mean age of $80 \mathrm{y}$, and $30 \%$ of them died during a 3-year follow-up. The age might restrict them from finding the association. Furthermore, the sleep pattern of their participants differed widely from other studies, that more $(11.5 \%$ 
medRxiv preprint doi: https://doi.org/10.1101/2020.04.09.20060277; this version posted April 14, 2020. The copyright holder for this preprint (which was not certified by peer review) is the author/funder, who has granted medRxiv a license to display the preprint in perpetuity. All rights reserved. No reuse allowed without permission.

vs. $<1 \%$ ) participants remained $\mathrm{LSD}^{24}$. The sleep duration in the Ohsaki Cohort 2006 study was recorded in 1994 and 2006. The human's sleep duration declines as age grows older ${ }^{28}$. The decline in sleep duration caused by the long follow-up time would affect the result ${ }^{23}$. The Whitehall Study had the relatively best study design, nonetheless, they did not find significance among people with SSD or have enough samples of LSD ${ }^{9}$. Remarkably, the findings in the 3 studies listed in Table 6 were not contradictory to our findings. These studies just did not reach our findings and repeated the previous conclusion that increased or decreased sleep duration would cause lower cognition. Last but not least, in our study, a change from LSD to MSD had no effect. The Chinese Longitudinal Healthy Longevity Survey reported a change from LSD to MSD could decreased the risk of dementia, and it could be a supplementary to our result.

Whether sleep duration affected the rate of cognitive change was controversial ${ }^{14,21,27,29-32}$. Some reported long sleep duration at baseline would lead to faster decline of cognition, while some reported that there was no association. Using GEE, we did not find association between baseline sleep duration and cognitive decline.

Table 6. Summary of studies that linked changes in sleep duration with cognitive function or dementia, using sub-group analysis

\begin{tabular}{|c|c|c|c|c|c|c|}
\hline References & Participants, & $\begin{array}{l}\text { Measures of } \\
\text { sleep duration }\end{array}$ & Cognitive tests and outcomes & $\begin{array}{l}\text { Significant } \\
\text { findings } \\
\text { for SSD } \\
\text { group }\end{array}$ & $\begin{array}{l}\text { Significant Findings } \\
\text { for MSD group }\end{array}$ & $\begin{array}{l}\text { Significant } \\
\text { Findings } \\
\text { LLD group }\end{array}$ \\
\hline $\begin{array}{ll}\text { Q. } & \text { Zhu } \\
2020 & \end{array}$ & $\begin{array}{l}5419 \text { Chinese } \\
\text { participants aged } 70-90 \mathrm{y} \\
\text { from the Chinese } \\
\text { Longitudinal Healthy } \\
\text { Longevity Survey }\end{array}$ & $\begin{array}{l}\text { Self-reported } \\
\text { total hours of } \\
\text { sleep in } 2008 \text { and } \\
2011 \text {; MMSE at } \\
\text { baseline and } \\
2011\end{array}$ & $\begin{array}{l}\text {-Two MMSE tests at baseline } \\
\text { and } 3 \text { y follow-up } \\
\text {-MCI } \\
\text { Criteria: follow-up MMSE } \\
\text { score }<18 \text { for no education, } \\
\text { MMSE }<21 \text { for primary } \\
\text { education, MMSE }<25 \text { or } \\
\text { middle education }\end{array}$ & None & $\begin{array}{l}\text {-Change to LSD was } \\
\text { associated with higher } \\
\text { risk of MCI, OR (1.41, } \\
3.39)\end{array}$ & $\begin{array}{l}\text {-Change to MSD } \\
\text { was associated } \\
\text { with less risk of } \\
\text { MCI, OR }(0.45 \text {, } \\
0.93)\end{array}$ \\
\hline Y. Lu 2018 & $\begin{array}{l}7422 \quad \text { Japanese } \\
\text { participants aged } \geq 65 \mathrm{y} \\
\text { from the Ohsaki Cohort } \\
2006 \text { study }\end{array}$ & $\begin{array}{l}\text { Self-reported } \\
\text { total hours of } \\
\text { sleep in } 1994 \text { and } \\
2006\end{array}$ & $\begin{array}{l}\text {-One Dementia Scale test } \\
\text { during } 2007 \text { and } 2012 \\
\text {-Incident dementia } \\
\text { Criteria: dementia Scale rank } \geq \\
2\end{array}$ & None & $\begin{array}{l}\text {-Change to LSD was } \\
\text { associated with higher } \\
\text { risk of incident } \\
\text { dementia, OR (1.13, } \\
1.72)\end{array}$ & None \\
\hline $\begin{array}{l}\text { J.E. Ferrie } \\
2011\end{array}$ & $\begin{array}{l}5431 \text { British participants } \\
\text { aged } 45-69 \text { from the } \\
\text { Whitehall Study }\end{array}$ & $\begin{array}{l}\text { Self-reported } \\
\text { total hours of } \\
\text { sleep in } 1997 \text { and } \\
2002\end{array}$ & $\begin{array}{l}\text {-One MMSE test at the end } \\
\text {-The score (ranged from } 0 \text { to } 30 \text { ) }\end{array}$ & None & $\begin{array}{l}\text {-Change to SSD was } \\
\text { associated with lower } \\
\text { cognition, beta }(-1.90 \text {, - } \\
0.49) \\
\text {-Change to LSD was } \\
\text { associated with lower }\end{array}$ & $\begin{array}{l}\text { Not enough } \\
\text { sample }\end{array}$ \\
\hline
\end{tabular}


medRxiv preprint doi: https://doi.org/10.1101/2020.04.09.20060277; this version posted April 14, 2020. The copyright holder for this preprint (which was not certified by peer review) is the author/funder, who has granted medRxiv a license to display the preprint in perpetuity.

All rights reserved. No reuse allowed without permission.

cognition, beta $(-2.74,-$

$0.72)$

Abbreviations: MCI, mild cognitive impairment; SSD, short sleep duration; MSD, moderate sleep duration; LSD, long sleep duration.

\subsection{Possible mechanisms explaining improvement in sleep duration and cognitive function}

The circadian rhythm was composed of clock genes in almost every cell of human body and part of the neuro-endocrine system. It provides humans with the adaption to the earth rotation every 24 hours. There was a bidirectional relationship between sleep duration, circadian rhythm and cognitive function ${ }^{6}$. Short or long sleep duration could disrupt circadian rhythm ${ }^{5}$. Numerous studies pointed to short or long sleep duration and disruption of circadian rhythm as a risk factor for neurodegenerative diseases, including dementia. ${ }^{4,33}$ Few clinical studies reported that restoration of circadian rhythm might reduce the deterioration of human's cognitive function, by using controlled light exposure or injection of melatonin, an endocrine hormone associated with circadian rhythm ${ }^{34-37}$. In an animal study, scientists improved the sleep duration of mice carrying the Huntington's Disease (HD) mutation, slowing down the cognitive decline of mice and reversed dysregulation of their circadian rhythm. ${ }^{38,39}$ These studies suggested that a change from LSD to MSD might restore the circadian rhythm and thus led to better cognitive function in our participants. Inversely, excessive change and deviation from MSD correlated with disruption of circadian rhythm, which was associated with worse cognitive function.

Furthermore, other mechanisms were discovered for explanation of the cross-sectional association between sleep duration and cognitive function, such as inflammatory markers, sleep apnea and sleep fragmentation. Nonetheless, whether change in sleep duration would affect these mediators was not clear.

\subsection{Advantages and limitations}

A strength of our study was its large and national-representative sample of middle-aged and older Chinese, who were enrolled in a prospective and up-to-date study. And, the robustness of the CHARLS survey allowed us to adjust for multiple confounders. 
medRxiv preprint doi: https://doi.org/10.1101/2020.04.09.20060277; this version posted April 14, 2020. The copyright holder for this preprint (which was not certified by peer review) is the author/funder, who has granted medRxiv a license to display the preprint in perpetuity.

All rights reserved. No reuse allowed without permission.

Our study also had several limitations. First, measurement of sleep duration was self-reported, which would be influenced by recall bias. C.L. Jackson 2018 studied the differences between self-reported and objectively measured sleep duration among several ethics. Compared with whites (73 min, 95\% CI: 67-79), blacks and Hispanics, Chinese had the lowest bias (49 min, 95\% CI: $37-61)^{40}$. Plenty of cohorts found association between self-reported sleep duration and unhealthy outcomes, making our research convincible ${ }^{41}$. Most importantly, self-reported measurement is cheap and practicable, increasing the applicable of our results for health education and general research. Second, sleepdisordered breathing (SDB), which was no designed in ours study, was viewed to affect cognition. 6,42,43. A recent study assessed 5247 participants with in-home polysomnography and found no association between cognitive function and SDB assessments, including Epworth Sleepiness Scale and Respiratory Event Index ${ }^{7}$. Third, 15.9\% of participants in Wave 1 lost to follow up in Wave 2 and 19.4\% lost to follow up in Wave 3. This might affect our result.

\subsection{For health education}

For short sleepers, a consistent change to moderate sleep duration correlated with better cognition. For long sleepers, there was no need to reduce sleep duration. Excessive changes over the moderate sleep duration or deviation from the moderate was associated with lower cognition.

\section{References}

1. Organization WH. World Alzheimer Report 2015: the global impact of dementia: an analysis of prevalence, incidence, cost and trends: Alzheimer's Disease International. 2015.

2. J. PGG. On the effect of loss of sleep. Psychol Rev. 1896;3:469-86.

3. Bubu OM, Brannick M, Mortimer J, et al. Sleep, Cognitive impairment, and Alzheimer's disease: A Systematic Review and Meta-Analysis. Sleep. 2017;40(1). 
medRxiv preprint doi: https://doi.org/10.1101/2020.04.09.20060277; this version posted April 14, 2020. The copyright holder for this preprint (which was not certified by peer review) is the author/funder, who has granted medRxiv a license to display the preprint in perpetuity.

All rights reserved. No reuse allowed without permission.

4. Musiek ES, Holtzman DM. Mechanisms linking circadian clocks, sleep, and neurodegeneration. Science. 2016;354(6315):1004-1008.

5. $\quad$ Lim AS, Saper CB. Sleep, circadian rhythms, and dementia. Ann Neurol. 2011;70(5):677-679.

6. Malkani RG, Zee PC. Sleeping well and staying in rhythm to stave off dementia. Sleep Med Rev. 2018;40:13.

7. Ramos AR, Tarraf W, Wu B, et al. Sleep and neurocognitive decline in the Hispanic Community Health Study/Study of Latinos. Alzheimers Dement. 2019.

8. Westwood AJ, Beiser A, Jain N, et al. Prolonged sleep duration as a marker of early neurodegeneration predicting incident dementia. Neurology. 2017;88(12):1172-1179.

9. Ferrie JE, Shipley MJ, Akbaraly TN, Marmot MG, Kivimaki M, Singh-Manoux A. Change in sleep duration and cognitive function: findings from the Whitehall II Study. Sleep. 2011;34(5):565-573.

10. Gildner TE, Salinas-Rodriguez A, Manrique-Espinoza B, Moreno-Tamayo K, Kowal P. Does poor sleep impair cognition during aging? Longitudinal associations between changes in sleep duration and cognitive performance among older Mexican adults. Arch Gerontol Geriat. 2019;83:161-168.

11. Zhao Y, Hu Y, Smith JP, Strauss J, Yang G. Cohort profile: the China Health and Retirement Longitudinal Study (CHARLS). Int J Epidemiol. 2014;43(1):61-68.

12. McArdle JJ, Ferrer-Caja E, Hamagami F, Woodcock RW. Comparative longitudinal structural analyses of the growth and decline of multiple intellectual abilities over the life span. Dev Psychol. 2002;38(1):115-142.

13. Qin T, Yan M, Fu Z, et al. Association between anemia and cognitive decline among Chinese middle-aged and elderly: evidence from the China health and retirement longitudinal study. BMC Geriatr. 2019;19(1):305.

14. Benito-Leon J, Bermejo-Pareja F, Vega S, Louis ED. Total daily sleep duration and the risk of dementia: a prospective population-based study. Eur J Neurol. 2009;16(9):990-997.

15. Lei X, Sun X, Strauss J, et al. Health outcomes and socio-economic status among the mid-aged and elderly in China: Evidence from the CHARLS national baseline data. J Econ Ageing. 2014;4:59-73.

16. Cheng ST, Chan AC. The Center for Epidemiologic Studies Depression Scale in older Chinese: thresholds 
medRxiv preprint doi: https://doi.org/10.1101/2020.04.09.20060277; this version posted April 14, 2020. The copyright holder for this preprint (which was not certified by peer review) is the author/funder, who has granted medRxiv a license to display the preprint in perpetuity.

All rights reserved. No reuse allowed without permission.

for long and short forms. Int J Geriatr Psychiatry. 2005;20(5):465-470.

17. Li J, Cacchione PZ, Hodgson N, et al. Afternoon Napping and Cognition in Chinese Older Adults: Findings from the China Health and Retirement Longitudinal Study Baseline Assessment. J Am Geriatr Soc. 2017;65(2):373-380.

18. Smiley A, King D, Bidulescu A. The Association between Sleep Duration and Metabolic Syndrome: The NHANES 2013/2014. Nutrients. 2019;11(11).

19. Wood SN. Low-rank scale-invariant tensor product smooths for generalized additive mixed models. Biometrics. 2006;62(4):1025-1036.

20. Laird NM, Ware JH. Random-effects models for longitudinal data. Biometrics. 1982;38(4):963-974.

21. Xu L, Jiang CQ, Lam TH, et al. Sleep duration and memory in the elderly Chinese: longitudinal analysis of the Guangzhou Biobank Cohort Study. Sleep. 2014;37(11):1737-1744.

22. Loerbroks A, Debling D, Amelang M, Sturmer T. Nocturnal sleep duration and cognitive impairment in a population-based study of older adults. Int J Geriatr Psychiatry. 2010;25(1):100-109.

23. Lu Y, Sugawara Y, Zhang S, Tomata Y, Tsuji I. Changes in sleep duration and the risk of incident dementia in the elderly Japanese: the Ohsaki Cohort 2006 Study. Sleep. 2018;41(10).

24. Zhu Q, Fan H, Zhang X, Ji C, Xia Y. Changes in sleep duration and 3-year risk of mild cognitive impairment in Chinese older adults. Aging (Albany NY). 2020;12(1):309-317.

25. Hahn EA, Wang HX, Andel R, Fratiglioni L. A Change in Sleep Pattern May Predict Alzheimer Disease. Am J Geriat Psychiat. 2014;22(11):1262-1271.

26. van Oostrom SH, Nooyens ACJ, van Boxtel MPJ, Verschuren WMM. Long sleep duration is associated with lower cognitive function among middle-age adults - the Doetinchem Cohort Study. Sleep Med. 2018;41:78-85.

27. Devore EE, Grodstein F, Duffy JF, Stampfer MJ, Czeisler CA, Schernhammer ES. Sleep duration in midlife and later life in relation to cognition. J Am Geriatr Soc. 2014;62(6):1073-1081.

28. Skeldon AC, Derks G, Dijk DJ. Modelling changes in sleep timing and duration across the lifespan: Changes 
medRxiv preprint doi: https://doi.org/10.1101/2020.04.09.20060277; this version posted April 14, 2020. The copyright holder for this preprint (which was not certified by peer review) is the author/funder, who has granted medRxiv a license to display the preprint in perpetuity.

All rights reserved. No reuse allowed without permission.

in circadian rhythmicity or sleep homeostasis? Sleep Med Rev. 2016;28:96-107.

29. Keage HAD, Banks S, Yang KL, Morgan K, Brayne C, Matthews FE. What sleep characteristics predict cognitive decline in the elderly? Sleep Medicine. 2012;13(7):886-892.

30. Song YS, Blackwell T, Yaffe K, et al. Relationships Between Sleep Stages and Changes in Cognitive Function in Older Men: The MrOS Sleep Study. Sleep. 2015;38(3):411-421.

31. Potvin $\mathrm{O}$, Lorrain $\mathrm{D}$, Forget $\mathrm{H}$, et al. Sleep quality and 1 -year incident cognitive impairment in communitydwelling older adults. Sleep. 2012;35(4):491-499.

32. Tworoger SS, Lee S, Schernhammer ES, Grodstein F. The association of self-reported sleep duration, difficulty sleeping, and snoring with cognitive function in older women. Alz Dis Assoc Dis. 2006;20(1):4148.

33. Kondratova AA, Kondratov RV. The circadian clock and pathology of the ageing brain. Nat Rev Neurosci. 2012;13(5):325-335.

34. Sekiguchi H, Iritani S, Fujita K. Bright light therapy for sleep disturbance in dementia is most effective for mild to moderate Alzheimer's type dementia: a case series. Psychogeriatrics. 2017;17(5):275-281.

35. Riemersma-van der Lek RF, Swaab DF, Twisk J, Hol EM, Hoogendijk WJ, Van Someren EJ. Effect of bright light and melatonin on cognitive and noncognitive function in elderly residents of group care facilities: a randomized controlled trial. JAMA. 2008;299(22):2642-2655.

36. Ancoli-Israel S, Gehrman P, Martin JL, et al. Increased light exposure consolidates sleep and strengthens circadian rhythms in severe Alzheimer's disease patients. Behav Sleep Med. 2003;1(1):22-36.

37. Wang YY, Zheng W, Ng CH, Ungvari GS, Wei W, Xiang YT. Meta-analysis of randomized, double-blind, placebo-controlled trials of melatonin in Alzheimer's disease. Int J Geriatr Psych. 2017;32(1):50-57.

38. Pallier PN, Maywood ES, Zheng Z, et al. Pharmacological imposition of sleep slows cognitive decline and reverses dysregulation of circadian gene expression in a transgenic mouse model of Huntington's disease. J Neurosci. 2007;27(29):7869-7878.

39. Pallier PN, Morton AJ. Management of sleep/wake cycles improves cognitive function in a transgenic mouse 
medRxiv preprint doi: https://doi.org/10.1101/2020.04.09.20060277; this version posted April 14, 2020. The copyright holder for this preprint (which was not certified by peer review) is the author/funder, who has granted medRxiv a license to display the preprint in perpetuity.

All rights reserved. No reuse allowed without permission.

model of Huntington's disease. Brain Res. 2009;1279:90-98.

40. Jackson CL, Patel SR, Jackson WB, Lutsey PL, Redline S. Agreement between self-reported and objectively measured sleep duration among white, black, Hispanic, and Chinese adults in the United States: MultiEthnic Study of Atherosclerosis. Sleep. 2018;41(6).

41. Jike M, Itani O, Watanabe N, Buysse DJ, Kaneita Y. Long sleep duration and health outcomes: A systematic review, meta-analysis and meta-regression. Sleep Med Rev. 2018;39:25-36.

42. Shi L, Chen SJ, Ma MY, et al. Sleep disturbances increase the risk of dementia: A systematic review and meta-analysis. Sleep Med Rev. 2018;40:4-16.

43. Yaffe K, Laffan AM, Harrison SL, et al. Sleep-disordered breathing, hypoxia, and risk of mild cognitive impairment and dementia in older women. JAMA. 2011;306(6):613-619.

\section{$7 \quad$ Acknowledgments}

We appreciated the China Center for Economic Research, the National School of Development of Peking University for providing the data.

\section{Author Contributions}

Jianian Hua contributed conception and design of the study. Yueping Shen organized the database. Jianian Hua performed the statistical analysis. Jianian Hua wrote the first draft of the manuscript. Yueping Shen and Hongpeng Sun reviewed the manuscript. All authors approved the final version of the paper.

\section{$9 \quad$ Ethics Statement}

Each participant included in this study signed a written informed consent form before taking the survey. Ethics approval for the data collection in the CHARLS was obtained from the Biomedical Ethics Review Committee of Peking University (IRB00001052-11015). We confirm that all methods were performed in accordance with the relevant guidelines and regulations. 
medRxiv preprint doi: https://doi.org/10.1101/2020.04.09.20060277; this version posted April 14, 2020. The copyright holder for this preprint

(which was not certified by peer review) is the author/funder, who has granted medRxiv a license to display the preprint in perpetuity.

All rights reserved. No reuse allowed without permission.

\section{Disclosure Statement}

Financial Disclosure: none. Non-financial Disclosure: none.

\section{DATA availability}

The data used in this manuscript from the China Health and retirement Longitudinal Study (CHARLS).

We applied the permission for the data access (http://charls.pku.edu.cn/zh-CN) and got the access to use it. Prof. Yaohui Zhao (National School of Development of Peking University), John Strauss (University of Southern California), and Gonghuan Yang (Chinese Center for Disease Control and Prevention) are the principle investigators.

\section{Funding}

This work was supported by the National Natural Science Foundation of China (project number 81973143) and the Priority Academic Program Development of Jiangsu Higher Education Institutions (PAPD). 